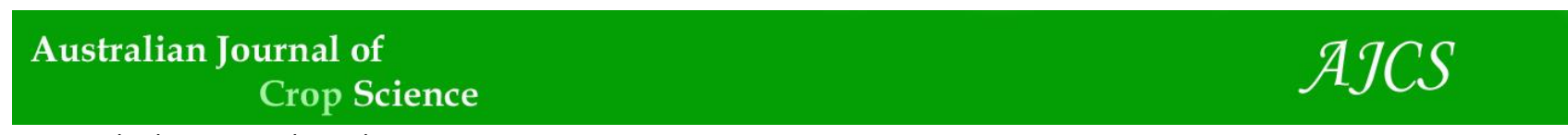

AJCS 12(06):990-994 (2018)

ISSN:1835-2707

doi: 10.21475/ajcs.18.12.06.PNE1090

\title{
Indirect estimation of leaf area in genotypes of 'Conilon' coffee (Coffea canephora Pierre ex A. Froehner)
}

\author{
Marcelo Curitiba Espindula ${ }^{1}$, Alexandre Martins Abdão dos Passos ${ }^{2}$, Larissa Fatarelli Bento Araújo ${ }^{3}$, \\ Alaerto Luiz Marcolan ${ }^{1}$, Fábio Luiz Partelli ${ }^{4}$, André Rostand Ramalho ${ }^{1}$
}

\author{
${ }^{1}$ Empresa Brasileira de Pesquisa Agropecuária, Centro de Pesquisa Agroflorestal de Rondônia - Embrapa Rondônia, \\ Brasil \\ ${ }^{2}$ Empresa Brasileira de Pesquisa Agropecuária - Embrapa Milho e Sorgo - Sete Lagoas, Minas Gerais, Brasil \\ ${ }^{3}$ Programa de Pós-Graduação em Ciências Ambientais, Campus de Rolim de Moura, Universidade Federal de \\ Rondônia, Rondônia, Brasil \\ ${ }^{4}$ Departamento de Ciências Agrárias e Biológicas, Centro Universitário Norte do Espírito Santo, Universidade Federal \\ do Espírito Santo, São Mateus - ES, Brasil
}

*Corresponding author: marcelo.espindula@embrapa.br

\begin{abstract}
Leaf area is an important parameter in agronomic and physiological studies; thereby, the techniques used for its determination should be simple, fast and accurate. The objective of this study was to evaluate the efficiency of an equation for the indirect determination of leaf area in 'Conilon' (Coffea canephora) genotypes cultivated in the Western Amazon. The experiment was carried out in Porto Velho, Rondônia, in August and September 2011. It was arranged in a completely randomized $2 \times 15$ factorial design combining two methods of determining leaf area (estimated and actual) and fifteen 'Conilon' coffee genotypes, with 64 replicates. The estimated leaf area was determined by the equation $L A=0.3064 \times \operatorname{Age}^{-0.0556} \times \operatorname{LMR}^{-2.0133}\left(R^{2}=0.98\right)$, developed by Partelli et al. (2006), while the actual leaf area was obtained from images of leaves scanned into digital format using an image scanner. The genotypes belong to the Coffee Breeding Program at Embrapa Rondônia. The efficiency of the equation for determining leaf area of 'Conilon' coffee varies according to the genotype evaluated; therefore, the equation must not be used without prior calibration. As the species is a perennial crop and the number of commercial genotypes widely accepted by farmers is restricted, the validation of the equation or the development of new equations capable of estimating the leaf area of the cultivated genotypes can help in the management of coffee plantationsn.
\end{abstract}

Keywords: Central rib length; Coffea canephora; leaf blade.

Abbreviations: LÂ_leaf area; CNC_central rib length

Introduction

Measuring leaf area is a useful tool to understand the dynamics of growth and development in a plant or in a set of plants within an agricultural crop system. This is possible because no other vegetative organ of the plant has so great polymorphism and adaptation to different environments and functions as the leaf. In addition, the leaf area is directly related to the photosynthetic process, since the larger the leaf area, the greater the light interception surface, which may result in high photosynthetic rates (Medrano and Flexas, 2003). Moreover, each leaf, depending on the degree of differentiation or the species, has the capacity to react to changes in its habitat by changing its metabolism, anatomy, and morphology in order to maintain photosynthetic efficiency. Therefore, research on the determination of leaf area under different environmental conditions is important for understanding the plant-environment relationship and can contribute to the selection of genotypes for productivity.
Currently, there are a number of methods to measure or estimate leaf area in plants. Leaf area can be determined by destructive methods, which consist in collecting leaves or other structures of the plant and are time and labor consuming; and non-destructive methods, which are divided into direct and indirect methods. Non-destructive direct methods, although easy, usually depend on expensive equipment (Ilkaee et al., 2011) and generally have the disadvantage that larger leaves cannot be assessed because of the limited reading area of the portable equipment (Schmildt et al., 2014). Non-destructive indirect methods are based on linear leaf dimensions and allow several evaluations in the same plant, in a fast and practical manner (Schmildt et al., 2016). There are several methods to determine the leaf area in coffee; however, in practice, mainly two are used: leaf dimensions and leaf area integrator (LA). The LA integrator method, commonly used as a reference, measures LA by counting the number of 
panes in a grid of known area (Licor, 1996); however, it is costly and destructive (Flumignan et al., 2008). Recently, with technological advances, there are methods using techniques for processing digital images that allow reliable results to be obtained for the leaf area of any vegetal species in a fast and efficient manner. Nevertheless, similarly to the leaf area integrator, these are destructive methods, which makes it difficult to follow the development of the crop cycle in the field and possible modifications.

In other crops, this problem has been solved by using nondestructive LA measurements, notably through mathematical models and regression equations, which has intensified research on this area. However, in coffee, especially for Coffea canephora species of the botanical varieties 'Conilon' and 'Robusta', these studies are rare to find in literature. Partelli et al. (2006) established an equation for indirect determination of the leaf area of 'Conilon' coffee using linear measurements of leaves. However, he developed the equation for a group of nonindividualized genotypes and crop environments of the state of Espírito Santo, which may compromise its efficiency in the determination of leaf area of genotypes under different genetic and cropping conditions.

Thus, considering the possibility of using the leaf area as an indicator of productivity and for monitoring the crop in the field, especially under stress conditions, this study aimed to evaluate the efficiency of the Partelli et al.'s (2006) equation in the indirect determination of leaf area in genotypes of 'Conilon' coffee grown in the Western Amazon.

\section{Results and discussion}

\section{Correlation between estimated and actual leaf area}

Positive correlation was found between the estimated and the actual leaf areas for all genotypes studied (Fig. 1 and 2). Positive correlation was also found for other species as reported by other authors that used equations considering the measurements rib length (Fideles Filho et al., 2010), blade width (Toebe et al., 2011) and/or the product of length and width of the blade (Lucena et al., 2011; Cargnelutti Filho et al., 2012; Bosco et al., 2012, Schwab et al., 2014), which had coefficient of determination above $90 \%$ when compared with the actual leaf areas. However, significant correlations are not enough to prove the efficiency of an equation, and it is necessary to determine whether the estimated area is different from the actual area, avoiding estimates that do not represent the true leaf area.

\section{Efficiency of the equation to estimate leaf area}

The comparison between the methods for determining the leaf area showed that there was no difference between the indirect method (estimated leaf area) and the direct method (actual leaf area) for the genotypes 2, 4, 5, 7, 8, 9, 12, 13, 14, and 15. However, for genotypes 1, 3, 6, 9, 10, and 11, the indirect method provided greater areas than the direct method, indicating that the equation overestimated the leaf area (Table 2).

The inefficiency of the indirect method for some genotypes may be related to the morphological differences of the leaves, reflecting the genetic and/or phenotypic differences between the genotypes that gave rise to Partelli et al.'s (2006) equation and the genotypes evaluated in this study. These differences are common in C. canephora because the species is allogamous with self-incompatibility, which occurs even in genotypes of the same variety (Covre et al., 2013). In addition, it is possible to form groups with distinct characteristics because of the high degree of molecular polymorphism in the species (Souza et al., 2013). Thus, the differences in leaf area observed are due to the genetic differences between the genotypes, since the Partelli et al.'s (2006) equation was based on a group of nonindividualized genotypes, without control of genotypic effects.

In addition to these genetic differences, allometric models developed to determine the leaf area, which consider only one dimension of the leaf and are established under very specific conditions, have been shown to be less efficient, and therefore their use is restricted. The reason for that is that leaves show morphoanatomic modifications in response to the action of biotic and abiotic factors. Under these circumstances, equations that use more than one leaf dimension and consider different shapes and sizes of leaves (Toebe et al., 2011), climate conditions (Barbosa et al., 2012), plant phenological stages (Partelli et al., 2006; Lucena et al., 2011), cropping conditions (Bosco et al., 2012), among other factors, have shown better fitting results, estimating the leaf area in different species with greater precision.

Thus, the results of this study indicate that the Partelli et al.'s (2006) equation is efficient to estimate the leaf area in genotypes of 'Conilon' coffee. However, changes in leaf morphology due to genetic diversity and environmental effects must be taken into account, and the equation must be validated for the genotype to be monitored for growth. Because coffee is a perennial crop and the genotypes released by breeding programs remain in the market for a long time, the adjustment of the equations for these materials can be justified.

\section{Materials and methods}

\section{Location and management history}

The experiment was carried out from August to September 2011 in the experimental field of Embrapa Rondonia in Porto Velho, RO, Brazil (latitude $08^{\circ} 47^{\prime} 56^{\prime \prime} \mathrm{N}$, longitude $63^{\circ} 50^{\prime}$ $49^{\prime \prime} \mathrm{W}$ and an altitude of $88 \mathrm{~m}$ asl). The region has an $\mathrm{Am}$ type climate (monsoon climate) and, according to climate data, mean air temperatures oscillate from $24^{\circ} \mathrm{C}$ to $26^{\circ} \mathrm{C}$, with a maximum from $30^{\circ} \mathrm{C}$ to $34^{\circ} \mathrm{C}$ and a minimum from 17 to $23^{\circ} \mathrm{C}$. Mean annual rainfall is $2,200 \mathrm{~mm}$ with a rainy season from October to May and dry season from June to September. The soil is classified as a Latossolo VemelhoAmarelo distrófico típico (Oxisol, Hapludox), with clayey texture.

The coffee field was planted with a spacing of $3 \times 2 \mathrm{~m}$, resulting in a density of 1,666 plants ha $^{-1}$. Crop management and treatments were carried out according to the needs and technical recommendations for the crop (EMBRAPA, 2009). At the time of field collections, the coffee trees were 33 months of age (after planting).

\section{Treatments and experimental design}

The experiment was carried out in a $2 \times 15$ factorial arrangement, resulting from the combination of two manners of determination of leaf area (direct and indirect) 
Table 1. Description of the Coffea canephora genotypes used in the study. Porto Velho, RO, Brazil, 2011.

\begin{tabular}{|c|c|c|c|}
\hline Genotype & Experimental number & Commercial name & $\begin{array}{l}\text { Group of gametophytic } \\
\text { incompatibility }\end{array}$ \\
\hline Clone 1 & K98M-0160 & RO C160 & 1 \\
\hline Clone 2 & K98M-0199 & RO C199 & ॥ \\
\hline Clone 3 & K98M-0125 & RO C125 & ॥ \\
\hline Clone 4 & K98M-0130 & RO C130 & III \\
\hline Clone 5 & K98M-0184 & RO C184 & $\|$ \\
\hline Clone 6 & K98M-0155 & RO C155 & III \\
\hline Clone 7 & K98M-0089 & RO C089 & I \\
\hline Clone 8 & K98M-0189 & RO C189 & I \\
\hline Clone 9 & K98M-0056 & RO C056 & II \\
\hline Clone 10 & K98M-0203 & RO C203 & I \\
\hline Clone 11 & K98M-0073 & RO C073 & III \\
\hline Clone 12 & K98M-0120 & RO C120 & I \\
\hline Clone 13 & K01P-0837 & non-commercial & 1 \\
\hline Clone 14 & K01M-0703 & non-commercial & undefined \\
\hline Clone 15 & K01T-0836 & non-commercial & III \\
\hline
\end{tabular}

*Commercial genotypes are part of the commercial polyclonal variety 'Conilon BRS Ouro Preto' (Ramalho et al., 2014). Non-commercial genotypes are being registered to become commercial genotypes.
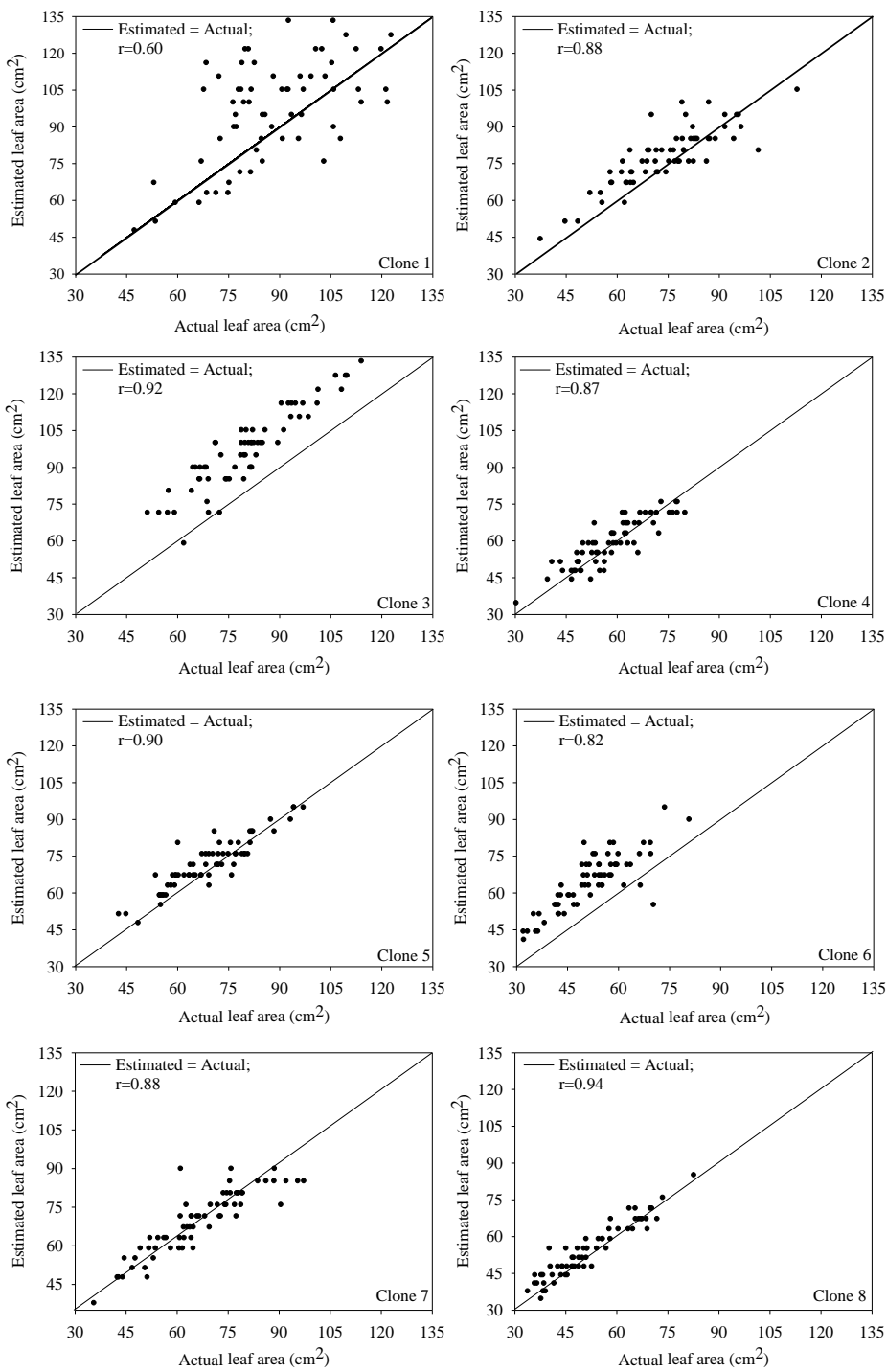

Fig 1. Pearson linear correlation coefficient between measurements of the estimated and actual leaf areas $\left(\mathrm{cm}^{2}\right)$ of eight genotypes of $\boldsymbol{C}$. canephora. All the coefficients were significant by the t test $(p \leq 0.05)$. Points in the graph represent the leaf area value estimated by equation, relative to its real area, fixed on the $X$ axis. The perpendicular line represents the point at which the estimated leaf area is equal to the real area. Points above the line indicate overestimation of the leaf area, points below the line indicate underestimation. 
Table 2. Estimated and actual leaf area of clones of $\boldsymbol{C}$. canephora coffee trees at 33 months of age. Porto Velho, RO, Brazil, 2011.

\begin{tabular}{|c|c|c|c|}
\hline \multirow{2}{*}{ Genotype } & \multicolumn{2}{|c|}{ Leaf area $\left(\mathrm{cm}^{2}\right)^{*}$} & \multirow{2}{*}{ VC (\%) } \\
\hline & Estimated & Actual & \\
\hline Clone 1 (160) & 96.33Aa & $87.91 \mathrm{Bb}$ & 20.94 \\
\hline Clone 2 (199) & $78.46 \mathrm{Ba}$ & $75.43 \mathrm{Ca}$ & 19.60 \\
\hline Clone 3 (125) & 97.76Aa & $81.23 \mathrm{Cb}$ & 18.40 \\
\hline Clone 4 (130) & $59.24 \mathrm{Ea}$ & $58.60 \mathrm{Ea}$ & 17.23 \\
\hline Clone 5 (184) & 71.74Ca & 69.27Da & 16.07 \\
\hline Clone 6 (155) & $64.52 \mathrm{Da}$ & $52.18 \mathrm{Fb}$ & 18.90 \\
\hline Clone 7 (089) & $69.30 \mathrm{Ca}$ & $66.68 \mathrm{Da}$ & 19.41 \\
\hline Clone 8 (189) & 53.60Fa & $51.36 \mathrm{Fa}$ & 22.28 \\
\hline Clone 9 (056) & $73.88 \mathrm{Ca}$ & $65.13 \mathrm{Db}$ & 18.65 \\
\hline Clone 10 (203) & $75.63 \mathrm{Ca}$ & $66.48 \mathrm{Db}$ & 26.86 \\
\hline Clone 11 (073) & $81.43 \mathrm{Ba}$ & $73.77 \mathrm{Cb}$ & 21.58 \\
\hline Clone 12 (120) & 58.97Ea & $57.28 \mathrm{Ea}$ & 16.34 \\
\hline Clone 13 (837) & $75.28 \mathrm{Ca}$ & $77.93 \mathrm{Ca}$ & 19.59 \\
\hline Clone 14 (703) & $80.23 \mathrm{Ba}$ & $76.64 \mathrm{Ca}$ & 16.95 \\
\hline Clone 15 (836) & 93.61Aa & $96.83 \mathrm{Aa}$ & 16.67 \\
\hline General average & & 72.88 & 19.69 \\
\hline
\end{tabular}

* Mean values followed by the same upper case letter in the column do not differ among themselves by the Scott-Knott test (p $\leq 0.05)$. Mean values followed by the same lower case letter in the line do not differ among themselves by the Tukey test $(p \leq 0.05)$.
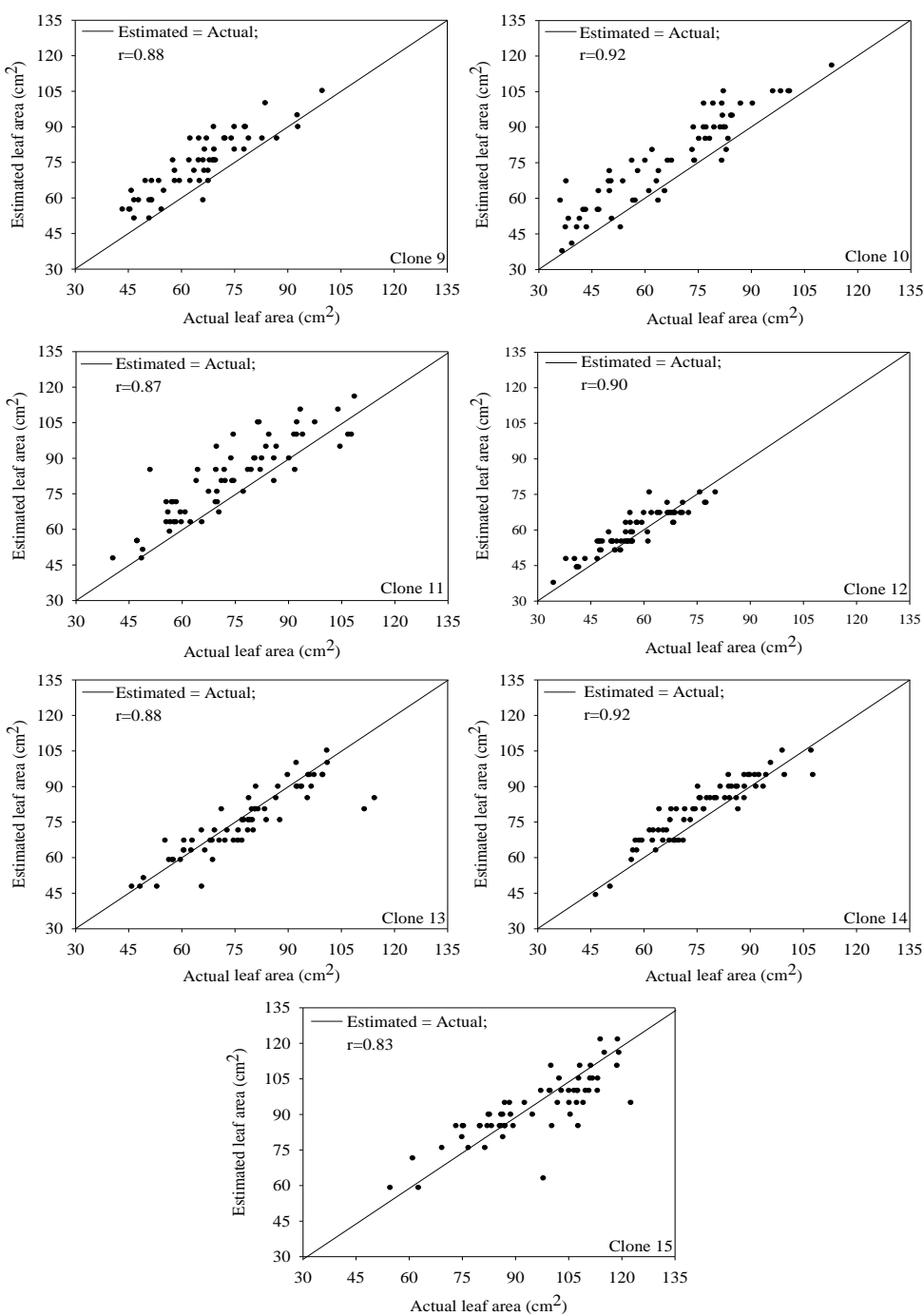

Fig 2. Pearson linear correlation coefficient between measurements of the estimated and actual leaf $\operatorname{areas}\left(\mathrm{cm}^{2}\right)$ of seven genotypes of $\boldsymbol{C}$. canephora. All the coefficients were significant by the test $(p \leq 0.05)$. Points in the graph represent the leaf area value estimated by equation, relative to its real area, fixed on the $X$ axis. The perpendicular line represents the point at which the estimated leaf area is equal to the real area. Points above the line indicate overestimation of the leaf area, points below the line indicate underestimation. 
and fifteen genotypes (clones) of coffee trees. A completely randomized experimental design with 64 replications was used. The clones were enumerated with cardinal numbers from 1 to 15 to represent the genotypes 160, 199, 125, 130, $184,155,089,189,056,203,073,120,837,703$ and 836, respectively (Table 1 ). The genotypes belong to the Coffee Breeding Program at Embrapa Rondônia. For each genotype, eight plants were selected, from which eight leaves were collected, one pair of leaves from each cardinal direction of the plant.

\section{Evaluations}

Direct determination of leaf area was performed through use of the software DDA - Digital Area Determiner (Ferreira et al., 2008) from images obtained in an image digitizer, considered as actual area. Indirect determination was obtained through the equation $\mathrm{LA}=0.3064 \times \mathrm{Age}^{-0.0556} \times \mathrm{LMR}^{-2.0133}\left(\mathrm{R}^{2}=0.98\right) \quad$ from measurements of the length of the mid rib (LMR) (Partelli et al., 2006), considered as estimated area.

\section{Statistical analysis}

The data obtained were subjected to analysis of variance and the mean values of the estimated and actual leaf areas were compared by the Tukey test $(p \leq 0.05)$. To verify the effects of genotypes, the estimated or actual mean values were grouped by the Scott-Knott test $(p \leq 0.05)$. The Pearson linear correlation coefficient $(p \leq 0.05)$ was also determined between the estimated and actual areas.

\section{Conclusion}

The efficiency of Partelli et al.'s equation to determine the leaf area of 'Conilon' coffee (C. canephora) varies according to the genotype evaluated; thus, the equation must be validated or adjusted for each genotype in study. As the species is a perennial crop and the number of commercial genotypes widely accepted by farmers is restricted, the validation of the equation or the development of new equations capable of estimating the leaf area of the cultivated genotypes can help in the management of coffee plantations.

\section{Acknowledgments}

Brazilian Consortium for Coffee Research and Development (Consórcio Pesquisa Café) by the financial support.

\section{References}

Barbosa JPRAD, Martins GA, Ferreira RT, Pennacchi JP, Souza VF, Soares AM (2012) Estimativa do iaf de cafeeiro a partir do volume de folhas e arquitetura da planta. Coffee Sci. 7(3):267-274

Bosco LC, Bergamaschi H, Cardoso LS, de Paula VA, Casamali B (2012) Seleção de modelos de regressão para estimar a área foliar de macieiras 'Royal gala'e 'Fuji suprema`sob tela antigranizo e em céu aberto. Rev Bras Frutic. 34(2):504-514.
Cargnelutti Filho A, Toebe M, Burin C, Fick AL, Casarotto G (2012) Estimativa da área foliar de nabo forrageiro em função de dimensões foliares. Bragantia. 71(1):47-51.

Covre AM, Partelli FL, Mauri AL, Dias MA (2013) Crescimento e desenvolvimento inicial de genótipos de café conilon. Rev Agr. On-line. 7:193-202.

EMBRAPA (2009) Sistema de Produção: Cultivo dos cafeeiros conilon e robusta para rondônia. 3 ed. 61 .

Ferreira OGR, Rossi FD, Andrighetto C (2008) DDA: Software para determinação de área foliar, índice de área foliar e área de olho de lombo. Versão 1.2. Santo Augusto.

Fideles Filho J, Beltrão NEM, Pereira AS (2010) Desenvolvimento de uma régua para medidas de área foliar do algodoeiro. Rev Bras Eng Agr Amb. 14 (7):736741.

Flumignan DL, Adami M, Faria RT (2008) Área foliar de folhas íntegras e danificadas de cafeeiro determinada por dimensões foliares e imagem digital. Coffee Sci. 3(1):1-6.

Ilkaee MN, Paknejad F, Zavareh M, Ardakani MR, kashani A (2011) Prediction model of leaf area in soybean (Glycine max I.). Am J Agr Bio Sci. 6(1):110-113.

Li-cor. Li 3100 (1996) Area Meter Instruction Manual. Lincoln: licor.

Lucena RRM, Batista TMV, Dombroski JLD, Lopes WAR, Rodrigues GSO (2011) Medição de área foliar de aceroleira. Rev Caatinga. 24(2):40-45.

Medrano H, Flexas J (2003) Fijación del dióxido de carbono e biosíntesis de fotoasimilados. In: Azcón-Bieto, J. and Talón, M. (ed.) Fundamentos de Fisiologia Vegetal. Mcgrawhill/Interamericana de España, S.A.U: Edicions Universiat de Barcelona.

Partelli FL, Viera HD, DETMAM E, CAMPOSTRINI E (2006) Estimativa da área foliar do Cafeeiro conilon a parir do comprimento da folha. Rev Ceres. 53(306):204- 210.

Ramalho AR, Rocha RB, Veneziano W, Santos MM (2014) Cultivar de cafeeiro conilon brs ouro preto - características agronômicas e agroindustriais. Porto Velho: Embrapa Comun. Técn. 396:1-9

Souza FF, Caixeta ET, Ferrão LFV, Pena G, Sakiyama NS, Zambolim EM, Zambolim L, Cruz CD (2013) Molecular diversity in coffea canephora germplasm conserved and cultivated in brazil. Crop Breed Appl Biot. 13:221-227.

Schwab NT, Streck NA, Rehbein A, Ribeiro BSMR, Ulhmann LO, Langner JÁ, Becker CC (2014) Dimensões lineares da folha e seu uso na determinação do perfil vertical foliar de gladíolo. Bragantia. 73(2):97-105.

Schmildt ER, Hueso JJ, Cuevas J (2014) Allometric models for determining leaf area of vine 'sugraone'. Cienc e Tec Vitivinic. 29:61-81.

Schmildt ER, Segantini LO, Schmildt O, Alexandre RS, Pires FR (2016) Determinação da área foliar de Passiflora mucronata a partir de dimensões lineares do limbo foliar. Rev Agroambiente. 10(4):351-357.

Toebe M, Cargnelutti Filho A, Burin C, Fick AL, Neu IMM, Casarotto G, Alves BM (2011) Modelos para a estimação da área foliar de feijão de porco por dimensões foliares. Bragantia 71(1):47-51. 